\title{
CYTOPATHIC FACTORS IN BACTERIA-FREE LYSATES OF ESCHERICHIA COLI
}

\author{
J. M. RUtTeR AND P. D. LUTHER \\ Agricultural Research Council, Institute for Research on Animal Diseases, \\ Compton, Newbury, Berkshire
}

\section{Plates XX-XXII}

STRAINS of Escherichia coli that are enteropathogenic for pigs have been shown to synthesise two forms of enterotoxin, described as heat-labile and heatstable, that cause fluid accumulation when introduced into ligated intestinal loops prepared in pigs or rabbits (Moon, Sorensen and Sautter, 1966; Smith and Halls, 1967; Gyles and Barnum, 1969; Moon et al., 1970; Smith and Gyles, $1970 a$ and $b$ ). Enterotoxin activity can also be demonstrated by feeding enterotoxin preparations to piglets (Kohler, 1968; Smith and Gyles, 1970a; Stevens, Gyles and Barnum, 1972). The limitations of the in-vivo techniques have prevented the characterisation of enterotoxins, and a simple, reliable test would be useful. The present report describes two factors in bacteria-free lysates of $E$. coli that are cytopathic for cell cultures prepared from pig thyroid glands. One of these factors is similar to heat-labile enterotoxin.

\section{MATERIALS AND METHODS}

Preparation and demonstration of enterotoxins. Bacteria-free lysates containing heatlabile enterotoxin (LT) were prepared as described by Smith and Gyles (1970a). Heat-stable enterotoxin (ST) was prepared by the soft-agar method of Smith and Halls (1967). LT and ST were demonstrated in ligated intestinal loops prepared in 8-wk-old pigs (Smith and Gyles, 1970a).

Preparation of the cell lines. Primary cultures of pig thyroid cells were prepared by the method of Witte and Easterday (1967) with slight modifications; disodium ethylenediamine tetra-acetate(EDTA) was added to 0.25 per cent. w/v trypsin solution (Difco Ltd, East Molesey, Surrey) to give a final concentration of 0.02 per cent. $v / v$ and the thyroid glands were processed at $37^{\circ} \mathrm{C}$. A suspension of pig thyroid cells containing $1.5 \times 10^{5}$ cells per $\mathrm{ml}$ was cultured in Earle's balanced salt solution in which glucose was replaced by galactose; the growth medium was supplemented with 0.5 per cent. w/v lactalbumen hydrolysate and 10 per cent. v/v calf serum (Flow Laboratories, Irvine, Ayrshire). Secondary cultures were prepared from 4- to 7-day-old primary cultures; the growth medium for secondary cultures was Medium 199 (Wellcome Reagents Ltd, Beckenham, Kent) containing galactose in place of glucose and supplemented with 10 per cent. $\mathrm{v} / \mathrm{v}$ calf serum. For further subcultures, the calf serum was replaced by 5 per cent. $\mathrm{v} / \mathrm{v}$ foetal calf serum (Flow Laboratories Ltd) and this was reduced to 2 per cent. in the maintenance medium.

Micro-assay test. The wells of tissue-culture "microtiter" plates (Biocult-Linbro Disposotrays, Biocult Laboratories, Paisley, Renfrewshire) were inoculated with $0.15 \mathrm{ml}$ pig-thyroidcell suspension containing $4 \times 10^{5}$ cells per $\mathrm{ml}$ in Medium 199; the plates were sealed with plastic tape and incubated at $37^{\circ} \mathrm{C}$ for 1-3 days. Ten-fold dilutions of the test materials were

Received 9 Mar. 1973; accepted 27 Apr. 1973.

J. MED. MICROBIOL.-Vot. 6 (1973) 
prepared in maintenance medium and after removal of the growth medium $0.15 \mathrm{ml}$ of the test dilution was added to each well. The plates were resealed and incubated for 2-3 days. The monolayers were stained for approximately $2 \mathrm{hr}$ with a solution containing equal volumes of 12 per cent. neutral buffered formalin (Lillie, 1954) and 0.2 per cent. gentian violet in 2 per cent. acetic acid. The plates were washed with tap water and dried, and the wells were examined microscopically for a cytopathic effect.

Morphology of the cell lines. Secondary cultures of pig thyroid cells in "microtiter" plates are cuboid and produce even monolayers. Up to passage no. 45 the cells remained cuboid, but numerous small discrete areas consisting of multi-layers of cells developed. From passage no. 45 to no. 52 these multi-layer areas became more compact and the surrounding monolayer fragmented to form spaces that were visible macroscopically in the cell sheet. By passage no. 57 , the cells had become "epithelial-like"; complete monolayers were again formed but these were interspersed with aggregates of cells arranged in parallel to form "cell sheaves". This pattern has continued up to passage no. 84 .

Neutralisation tests. Bacteria-free lysates were diluted to contain approximately 100 TCD $_{50}$ of cell-culture activity and added to doubling dilutions of adult pig serum. The mixtures were held at room temperature for $1 \mathrm{hr}$ and then tested for cytopathic activity. To compare the neutralisation of activity against cell cultures and ligated intestinal loops, $2 \mathrm{ml}$ or $6 \mathrm{ml}$ serum were added to $6 \mathrm{ml}$ lysate and after standing for $30 \mathrm{~min}$. at room temperature the mixtures were assayed in both systems.

\section{Results}

\section{Cytopathic activity of porcine enteropathogenic strains of Escherichia coli}

Bacteria-free lysates from most strains of $E$. coli produced a weak cytopathic effect (CPE) on the pig-thyroid-cell line; the CPE was detectable at $10^{-1}$ and occasionally at $10^{-2}$ dilutions of the lysates, was not reduced by heating at $65^{\circ} \mathrm{C}$ for $10 \mathrm{~min}$., and may be attributable to endotoxin. In contrast, bacteria-free lysates from K88-positive porcine enteropathogenic strains of $E$. coli contained a heat-labile factor that was cytopathic for cultures of pig-thyroid cells; this factor was demonstrable in lysates diluted $10^{-4}$ or $10^{-5}$ and was designated cytopathic factor I (CPFI). The CPE depended on the passage number of the cell line; initially, the cell line (passage nos. 1-45) formed a complete monolayer and addition of the bacterial lysates caused a CPE. Later, the cell line (passage nos. 45-52) formed an incomplete cell sheet (see Methods); CPFI appeared to prevent the formation of multi-layer areas and spaces so that an almost complete monolayer was produced. After passage no. 57, the control monolayer again became complete, and CPFI produced a CPE similar to that obtained with earlier passages. Most of the present results refer to tests in which the cell line had undergone 57-84 passages and in which the complete monolayer consisted of "epithelial-like" cells interspersed with "cell sheaves" (figs. 1 and 2). In these tests, CPFI caused fragmentation of the cell sheet and disruption of the "cell sheaves" so that the cell cytoplasm became spindle-like and many cells were linked by strands of cytoplasm (figs. 3 and 4).

Examination of the lysates in the electron microscope did not reveal the presence of viruses or mycoplasmas; serial passage of the lysates in pig thyroid cells demonstrated that the cytopathic agent was not transmissible.

Distribution of CPFI. CPFI was present in all of 20 bacteria-free lysates from K88-positive porcine enteropathogenic strains associated with neonatal 


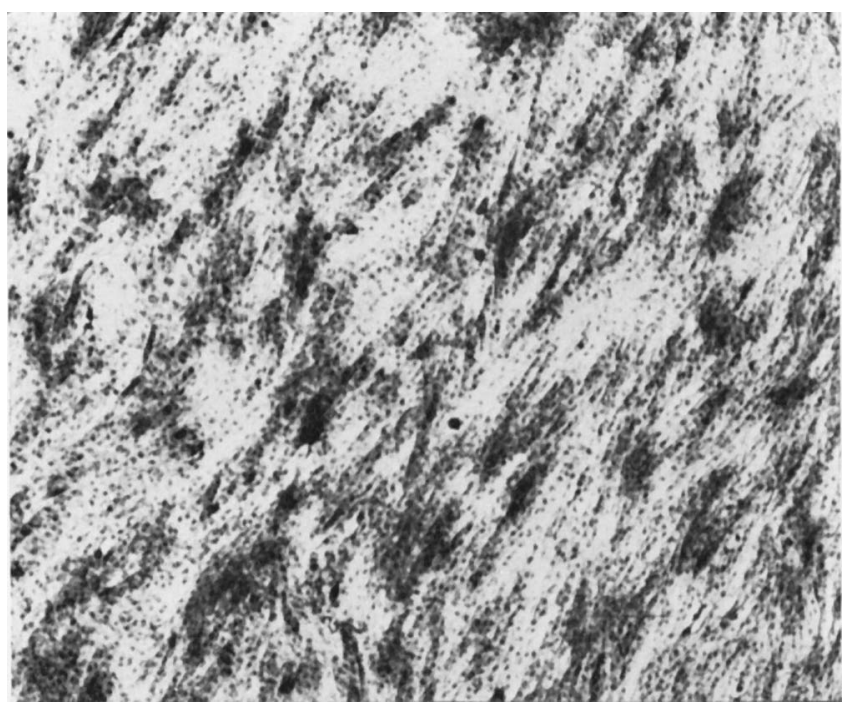

Fig. 1.-Normal monolayer of pig thyroid cell line (passage no. 57-84). Epithelial-like cells are interspersed with aggregates of cells arranged in parallel to form "cell sheaves". Stained. $\times 40$.

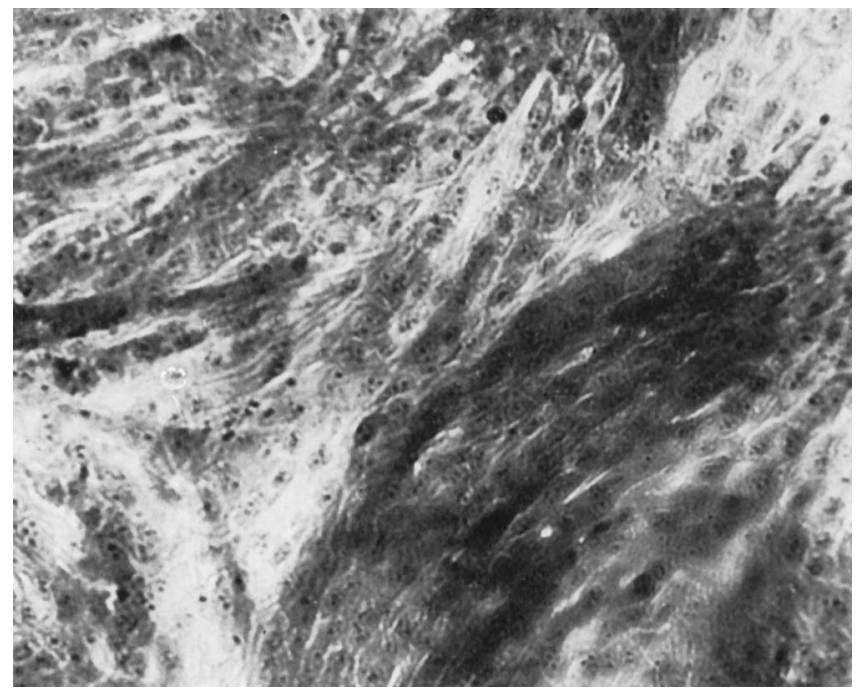

Fig. 2.-As fig. 1 , but $\times 200$. 
CYTOPATHIC FACTORS IN $E$. COLI LYSATES

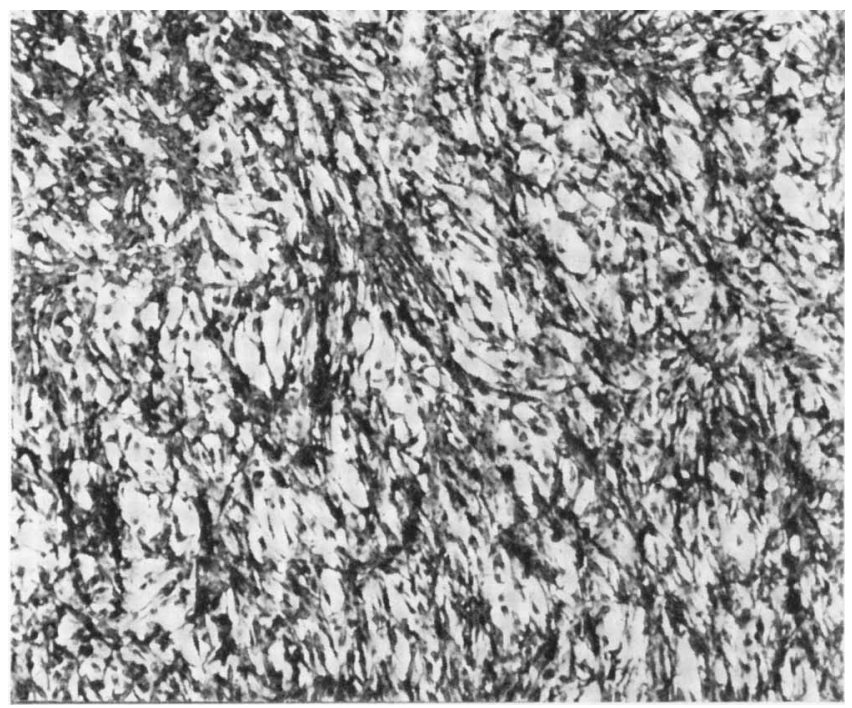

Fig. 3.-Effect caused by cytopathic factor I (lysate diluted $10^{-3}$ ); the cell sheet is fragmented, "cell sheaves" are disrupted and some cells are linked by elongated strands of cytoplasm. Stained. $\times 40$.

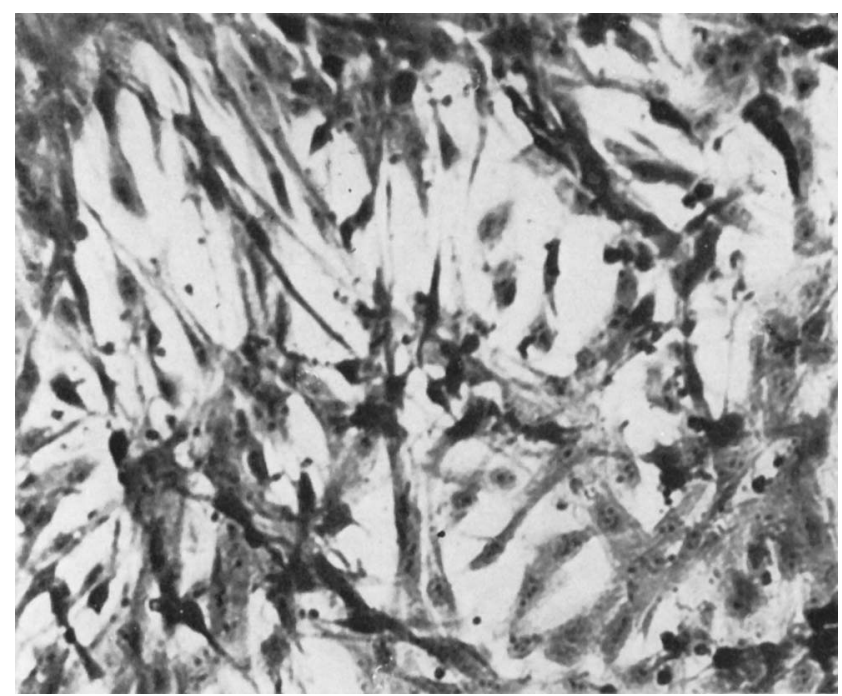

FIG. 4. -As fig. 3, but $\times 200$. 


\section{CyTOPATHIC FACTORS IN $E$. COLI LYSATES}

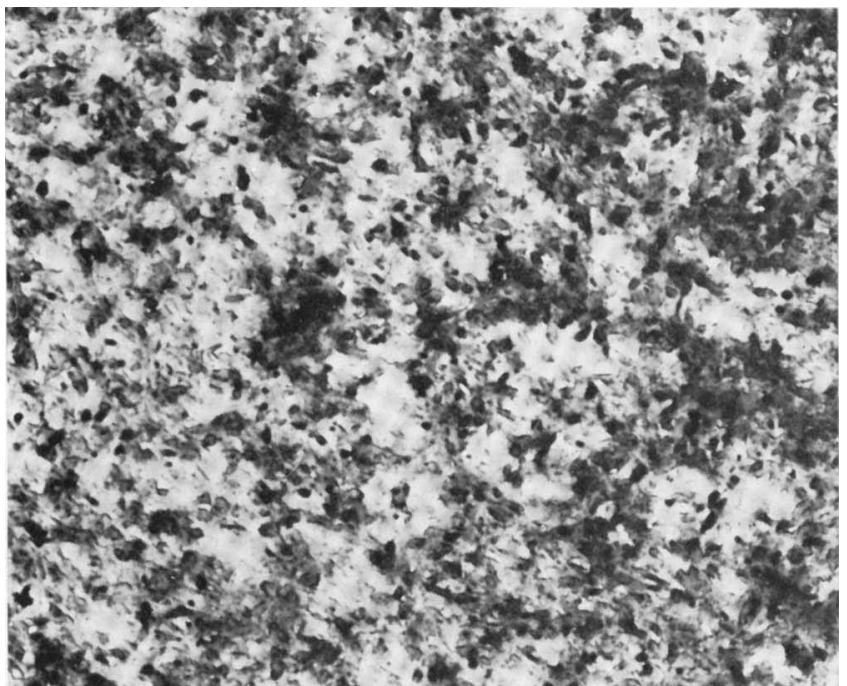

FIG. 5.-Effect caused by cytopathic factor II (lysate diluted $10^{-3}$ ); the cell sheet shows little fragmentation and the cells become enlarged and more cuboid. Stained. $\times 40$.

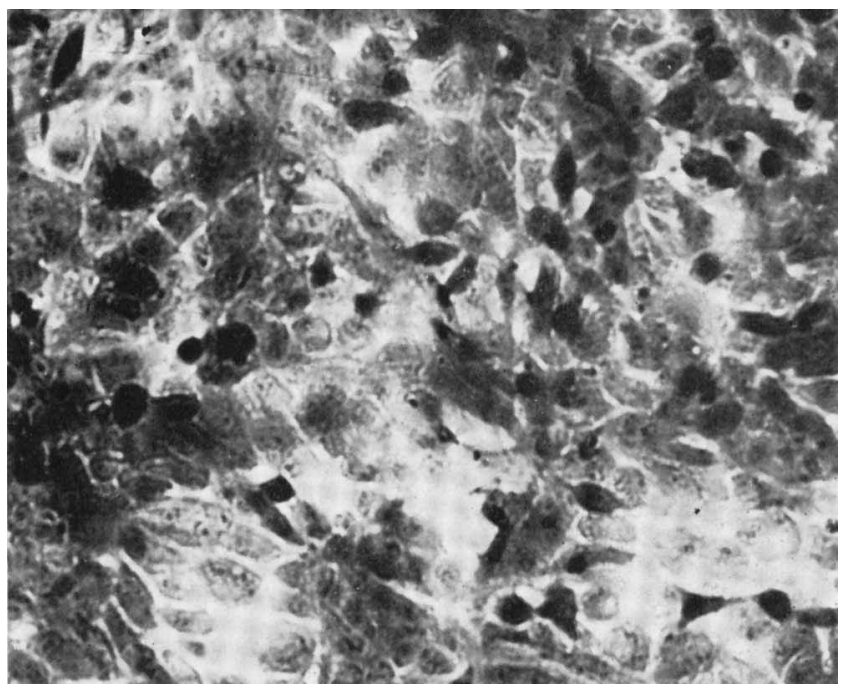

Fig. 6. - As fig. 5 , but $\times 200$. 
diarrhoea in piglets. The strains represented OK groups O8:K87,K88ab (three strains), O8:K87,K88ac (three strains), O141:K85,K88ab (four strains), O147:K89,K88ac (three strains), O149:K91,K88ac (five strains), O45:KE65,K88ac (one strain) and O158:KV17,K88ac (one strain). In general, the end point of titrations of lysates that contained CPFI was between $10^{-4}$ and $10^{-5}$, and the titre was not significantly reduced after storage for several months at $-20^{\circ} \mathrm{C}$. Five lysates were tested in the cell-culture system and in ligated intestinal loops prepared in pigs; all contained LT and CPFI. ST preparations from these strains produced dilatation of ligated intestinal loops but had no cytopathic activity.

In contrast, bacteria-free lysates from seven strains associated with oedema disease and post-weaning diarrhoea representing OK groups O138:K81, O139:K82, O141:K85ab-ac, O45:KE65 and 0141:K85 did not produce LT or a CPE. ST preparations from three of these strains produced dilatation of ligated intestinal loops, but none produced a CPE.

Lysates from three atypical piglet enteropathogenic strains representing OK groups O101:K? and O64:K? did not produce a CPE; as expected, we failed to demonstrate LT or ST in ligated loops prepared in 8-wk-old piglets (see Smith and Linggood, 1972).

Relationship of CPFI to K88 antigens and haemolysins. The above results indicated that CPFI is present in LT preparations of K88-positive porcine enteropathogenic strains of $E$. coli. In addition to LT and ST these strains produce K88 antigen and usually haemolysins. CPFI is not attributable to K88 antigen because (i) K88-negative mutant strains derived by different treatments from a strain of the O149:K91(B),K88ac(L):H10 serotype (Jones and Rutter, 1972) produced CPFI and LT, (ii) two $\mathrm{K}_{12 \mathrm{~F}^{-}}$strains into which the K88 plasmid had been transferred did not acquire CPFI, and (iii) cell-free partially-purified K88 antigen (Jones and Rutter) did not possess cell-culture activity. CPFI is not attributable to haemolysins because (i) the strains associated with oedema disease and post-weaning diarrhoea are haemolytic but do not produce CPFI (ii) one of the K88-positive enteropathogenic strains was not haemolytic yet produced CPFI, and (iii) two strains that had received the enterotoxin(Ent) plasmids (q.v.) were not haemolytic but produced CPFI.

Transmission of CPFI. The ability to synthesise LT is transmitted with ST from donor to recipient strains of E. coli (Smith and Gyles, 1970a). We tested a $\mathrm{K}_{12} \mathrm{~F}^{-}$strain and a fowl strain before and after they had received the Ent plasmids from a donor strain of serotype $08: \mathrm{K} 87, \mathrm{~K} 88 \mathrm{ab}^{-}$. Before introduction of the Ent plasmids, the recipient strains produced no cell-culture activity; after introduction of the plasmids, both recipient strains produced CPFI, LT and ST.

Physical characters of CPFI. The cytopathic activity of CPFI was reduced by 99.9 per cent. by heating at $60^{\circ} \mathrm{C}$ for $15 \mathrm{~min}$. CPFI was not dialysed through Visking dialysis tubing; it was precipitated by 80 per cent. saturated ammonium sulphate and was excluded from Sephadex G-200. A phenol-water extract (Kabat and Mayer, 1961) of a strain that produced CPFI had no cytopathic activity. 
Neutralisation of CPFI. Sera from 12 of 20 adult pigs neutralised CPFI; the dilutions of sera that neutralised 100 TCD50 of CPFI ranged from 1 in 20 to 1 in 320 (median 1 in 80). Six of the sera were selected to compare neutralisation of cytopathic activity and ligated intestinal-loop activity. Of these, two completely neutralised the CPFI content of a lysate; they also neutralised the same lysate in respect of its activity on the ligated intestinal loop. In general, sera neutralised the ligated intestinal-loop activity of the lysate more effectively than the cytopathic activity; this may be attributable to the greater sensitivity of the cell-culture test. The results of these neutralisation tests provided preliminary evidence that the same sera neutralised both activities and further studies of the neutralisation of CPFI are in progress.

\section{Cytopathic activities of other preparations}

Bacteria-free lysates from six of 35 apparently non-pathogenic strains of $E$. coli isolated from piglets and pigs also contained a factor that was cytopathic for pig-thyroid cells. The CPE differed morphologically from that caused by CPFI and so the factor was designated CPFII. The end-point of titrations of CPFII was between $10^{-4}$ and $10^{-5}$. CPFII caused little fragmentation of the monolayer (passage nos. 57-84); the cells became enlarged and more cuboid with disruption of the "cell sheaves" (figs. 5 and 6). Although the heat-lability of CPFI and CPFII is similar, we were unable to demonstrate LT or ST production by strains that produced CPFII. CPFII was not neutralised by the pig sera that neutralised CPFI and the nature of this factor has not yet been determined.

Bacteria-free lysates from five strains of $E$. coli isolated from calves with diarrhoea produced no CPE on cell cultures of pig thyroid glands. In contrast, lysates from six of 18 strains of $E$. coli associated with infantile diarrhoea contained cytopathic activity. The six lysates were prepared from strains belonging to OK groups O18ac:K77, O26:B6, O55:B5, O86:B7 and O119:B14 (two strains). The CPE produced by lysate O18ac:K77 resembled CPFII, but the CPE produced by the other five lysates differed morphologically from CPFI and CPFII.

A sample of cholera enterotoxin (purified choleragen, batch no. VT 2056B, Wellcome Research Laboratories) caused a CPE that was indistinguishable from CPFI, and further studies are in progress to elucidate the relationship of these cytopathic factors to CPFI and CPFII.

\section{Discussion}

There is increasing evidence that the ability to synthesise enterotoxin may be an important virulence determinant in strains of $E$. coli that are enteropathogenic for pigs (Smith and Halls, 1967; Kohler, 1968; Gyles and Barnum, 1969; Smith and Linggood, 1971). Although enterotoxins can be demonstrated by the ligated intestinal-loop procedure or by feeding preparations containing enterotoxins to piglets, these techniques have a number of limitations. A comparatively large amount of enterotoxin is necessary to produce fluid accumulation or diarrhoea so that assays cannot be made adequately quantitative; this 
is a major problem in fractionation and purification studies. The ligated-loop procedure in pigs may give variable results (Truszczynski and Pilaszek, 1969); only the anterior portion of the small intestine responds reliably and some pigs are completely unreactive to the test material (Smith and Gyles, 1970a). The rabbit gut-loop model gives comparatively non-specific results with LT preparations and inconsistent reactions with ST preparations (Lariviere, 1972). Reliable and simple techniques to demonstrate enterotoxins are necessary because enterotoxin synthesis is one of the criteria by which a strain may be classified as potentially pathogenic. In addition, the characterisation of enterotoxins and studies of their modes of action depend on adequate and sensitive assay systems.

Although cytopathic activity is useful for the in-vitro assay of many bacterial toxins (Solotorovsky and Johnson, 1970), the technique has not previously been applied to the enterotoxins of $E$. coli. Transformation of the pig-thyroid-cell line and the production of a CPE by CPFI seem to be reproducible. A similar pattern of transformation was observed with two other pig-thyroid-cell lines. Monolayers of secondary cultures from 24 different batches of pig-thyroid glands also showed a CPE after incubation with CPFI; however, monolayers from two batches of glands were comparatively insensitive in the test. Other cell cultures tested included secondary cultures from calf-, pig- and rabbit-kidney tissue, the MDBK bovine-kidney-cell line (Madin and Darby, 1958) and the SK-6 swine-kidney-cell line (Kasza, Shadduck and Christofinis, 1972). These cultures either showed a weak CPE or remained unaffected when exposed to $10^{-1}$ or less frequently $10^{-2}$ dilutions of lysates containing CPFI. In contrast, some secondary cultures of calf-thyroid cells and a calf-thyroid-cell line were as sensitive as pig-thyroid cells to lysates that contained CPFI. Thus, thyroid-cell cultures appear to be particularly susceptible to CPFI.

CPFI is similar to the LT type of enterotoxin. All of 20 strains known to produce LT and ST produced CPFI, but ST preparations from these strains had no cytopathic activity. Lysates of strains that produced only ST had no cytopathic activity. Furthermore, CPFI and enterotoxin activity were transmitted to two recipient strains by a donor strain. The heat lability of CPFI provides additional evidence that the cytopathic activity is not due to ST or to endotoxin. The results of dialysis, precipitation and gel-filtration of CPFI are similar to those obtained with LT (Gyles and Barnum; Lariviere). The cell-culture system is much more sensitive than in-vivo techniques for the demonstration of LT; less than $1 \mu \mathrm{g}$ of protein per test-well produced a detectable CPE, whereas $500 \mathrm{mg}$ are necessary to produce diarrhoea in piglets aged 1-3 days (Stevens, Gyles and Barnum, 1972) and approximately 50-100 $\mathrm{mg}$ are normally injected into ligated loops. Although the present results provide circumstantial evidence that LT and CPFI are identical, final proof will depend on the demonstration that both activities are produced by the same substance and are neutralised by sera in proportion to their anti-LT content. Smith and Gyles (1970a) reported that LT is neutralised by specific antisera prepared in pigs. Our observation that both CPFI and LT are neutralised by some adult pig sera may be attributable to previous natural exposure of these animals to strains of $E$. coli that produce LT.

LT may be related to cholera enterotoxin (Gyles and Barnum; Smith, 
1972). Cell-culture assays have been described for the detection of cholera enterotoxin (Vaughan, Pierce and Greenough, 1970; Inwood and Tyrrell, 1970) and it is of interest that a sample of cholera enterotoxin caused a CPE in pigthyroid-cell cultures that was indistinguishable from CPFI. Cell-culture tests may help to elucidate the relationship of these enterotoxins.

The heat-labile cytopathic factor designated CPFII in lysates of apparently non-pathogenic porcine strains of $E$. coli produced a CPE that was morphologically different from that of CPFI. The CPE was demonstrable in lysates diluted $10^{-4}$ or $10^{-5}$ but the nature of CPFII was not determined. In addition, lysates of certain human strains produced a CPE in pig-thyroid-cell cultures. Some human strains of $E$. coli produce an LT-type enterotoxin (Smith and Gyles, 1970b) and further studies are now in progress to determine the relationship of these cytopathic factors to CPFI and CPFII.

The CPE caused by CPFI is consistently reproducible and can be quantitated. The similarities of CPFI and LT suggest that the cell-culture system may provide a simple, sensitive assay for LT that requires only the facilities of a cell-culture laboratory. The test could prove useful in the characterisation of LT and may stimulate a search for other cell-culture systems that are sensitive to the enterotoxins of $E$. coli.

\section{SUMMARY}

A factor (CPFI) that caused a cytopathic effect on cultures of pig-thyroid cells was detected in bacteria-free lysates of K88-positive porcine enteropathogenic strains of Escherichia coli. CPFI was produced only by strains that synthesised heat-labile enterotoxin (LT) and was present in lysates that contained LT but was not associated with heat-stable enterotoxin, $\mathrm{K} 88$ antigens or haemolytic substances. CPFI was transmitted with LT from a donor to recipient strains; the factor was heat labile, non-dialysable, precipitated by ammonium sulphate and excluded from Sephadex G-200. CPFI was neutralised by some adult pig sera. Another factor (CPFII) that caused a morphologically different cytopathic effect on cultures of pig-thyroid cells was detected in bacteria-free lysates of six apparently non-pathogenic strains of $E$. coli isolated from pigs. CPFII was not related to the above products of $E$. coli and was not neutralised by pig sera. It is suggested that CPFI is similar to LT and that the cytopathic effect of CPFI could provide a simple, sensitive assay that may be of value in the characterisation of LT.

We are grateful to Dr Joan Taylor, Dr H. W. Smith, Mr W. J. Sojka and Dr L. Nagy for providing strains of Escherichia coli; also to Dr R. O. Thomson for the gift of cholera enterotoxin. We thank Mrs C. Jay, Miss S. Wilsdon, Mr M. Burrows, Mrs M. Martin and Mrs L. Shanks for their expert assistance, and Mr I. Jebbett for the photographs. 


\section{REFERENCES}

GyLES, C. L., AND BARNuM, D. A. 1969. A heat-labile enterotoxin from strains of Escherichia coli enteropathogenic for pigs. J. Infect. Dis., 120, 419.

INWOOD, JANET, AND TYRRELL, D. A. J. 1970. A cytotoxic factor in cholera toxin. Br. J. Exp. Path., 51, 597.

JoNes, G. W., AND RUTTER, J. M. 1972. Role of the K88 antigen in the pathogenesis of neonatal diarrhoea caused by Escherichia coli in piglets. Infect. Immun., 6, 918 .

Kabat, E. A., AND MAYER, M. M. 1961. Experimental immuno-chemistry, 2nd ed., Springfield, p. 833.

Kasza, L., Shadduck, J. A., ANd Christofinis, G. J. 1972. Establishment, viral susceptibility and biological characteristics of a swine kidney cell line SK-6. Res. Vet. Sci., $13,46$.

KOHLER, E. M. 1968. Enterotoxic activity of filtrates of Escherichia coli in young pigs. Am.J. Vet. Res., 29, 2263.

LARIVIERE, S. 1972. Physical and biological characterization of Escherichia coli enterotoxin. Diss. Abstr. B, 32(8), 4385-B.

LILLIE, R. D. 1954. Histopathologic technic and practical histochemistry, New York, p. 32.

MADIN, S. H., AND DARBY, N. B. 1958. Established kidney cell lines of normal adult bovine and ovine origin. Proc. Soc. Exp. Biol. Med., 98, 574.

MoON, H. W., SORENSEN, D. K., AND SAUTTER, J. H. 1966. Escherichia coli infection of the ligated intestinal loop of the newborn pig. Am. J. Vet. Res., 27, 1317.

Moon, H. W., Whipp, S. C., Engstrom, G. W., AND BAETZ, A. L. 1970. Response of the rabbit ileal loop to cell-free products from Escherichia coli enteropathogenic for swine. J. Infect. Dis., 121, 182.

SMrTH, H. W. 1972. The production of diarrhoea in baby rabbits by the oral administration of cell-free preparations of enteropathogenic Escherichia coli and Vibrio cholerae: the effect of antisera. J. Med. Microbiol., 5, 299.

SMITH, H. W., AND GYLES, C. L. 1970a. The relationship between two apparently different enterotoxins produced by enteropathogenic strains of Escherichia coli of porcine origin. J. Med. Microbiol., 3, 387.

SMITH, H. W., AND GyLES, C. L. 1970b. The effect of cell-free fluids prepared from cultures of human and animal enteropathogenic strains of Escherichia coli on ligated intestinal segments of rabbits and pigs. J. Med. Microbiol., 3, 403.

Smith, H. W., and Halls, Sheml 1967. Studies on Escherichia coli enterotoxin. J. Path. Bact., 93, 531.

SMITH, H. W., AND LingGoOd, Margaret A. 1971. Observations on the pathogenic properties of the K88, Hly and Ent plasmids of Escherichia coli with particular reference to porcine diarrhoea. J. Med. Microbiol., 4, 467.

SMITH, H. W., AND LINGGOOD, MARGARET A. 1972. Further observations on Escherichia coli enterotoxins with particular regard to those produced by atypical piglet strains and by calf and lamb strains: the transmissible nature of these enterotoxins and of a $\mathrm{K}$ antigen possessed by calf and lamb strains. J. Med. Microbiol., 5, 243.

Solotorovsky, M., AND Johnson, W. 1970. Tissue culture and bacterial protein toxins, In Microbial toxins, edited by S. J. Ajl, S. Kadis and T. C. Montie, New York, vol. 1, p. 277.

Stevens, J. B., Gyles, C. L., AND Barnum, D. A. 1972. Production of diarrhoea in pigs in response to Escherichia coli enterotoxin. Am. J. Vet. Res., 33, 2511.

TruszczYNSKI, M., AND PIlaszek, J. 1969. Effects of injection of enterotoxin, endotoxin or live culture of Escherichia coli into the small intestine of pigs. Res. Vet. Sci., 10, 469.

Vaughan, Martha, Pierce, N. F., and Greenough, W. B. 1970. Stimulation of glycerol production in fat cells by cholera toxin. Nature, Lond., 226, 658.

WrTte, K. H., AND EASTERDAY, B. C. 1967. Isolation and propagation of the virus of transmissible gastroenteritis of pigs in various pig cell cultures. Arch. ges.Virusforsch., 20, 327. 